Meta

Journal des traducteurs

Translators' Journal

\title{
In Memoriam Katharina Reiß
}

\section{Christiane Nord}

Volume 63, numéro 1, avril 2018

URI : https://id.erudit.org/iderudit/1050510ar

DOI : https://doi.org/10.7202/1050510ar

Aller au sommaire du numéro

Éditeur(s)

Les Presses de l’Université de Montréal

ISSN

0026-0452 (imprimé)

1492-1421 (numérique)

Découvrir la revue

Citer ce document

Nord, C. (2018). In Memoriam Katharina Reiß. Meta, 63(1), 1-2.

https://doi.org/10.7202/1050510ar

Ce document est protégé par la loi sur le droit d'auteur. L'utilisation des services d'Érudit (y compris la reproduction) est assujettie à sa politique d'utilisation que vous pouvez consulter en ligne.

https://apropos.erudit.org/fr/usagers/politique-dutilisation/
Cet article est diffusé et préservé par Érudit.

Érudit est un consortium interuniversitaire sans but lucratif composé de l'Université de Montréal, l'Université Laval et l'Université du Québec à Montréal. Il a pour mission la promotion et la valorisation de la recherche. https://www.erudit.org/fr/ 


\section{In Memoriam Katharina Reiß}

The world of translation studies has lost one of its greatest scholars and most inspiring teachers. On April 16 ${ }^{\text {th }}, 2018$, Katharina Reiß died peacefully in Munich, where she had lived for the last few decades. I received the notice by email on the $17^{\text {th }}$, the day which would have been her $95^{\text {th }}$ birthday. On that day, I had a plenary talk on functionalism at a translation studies conference in Tijuana, Mexico, and when I told the audience what had happened, they were all silent. They had not known her personally, but each of them had heard at least her name or even read some of her publications.

Katharina Reiß was born in 1923. Before becoming a pioneer of translation studies, which still was in its infancy at the time, she studied romance languages and literature, and translated several works from Spanish into German, among them José Ortega y Gasset's famous essay on the "misery and splendour of translation", Miseria y esplendor de la traducción. Her practical translation work provided the material for her translation classes at the School for Translation and Interpreting at the University of Heidelberg, Germany, which I attended in the early 1960s. She was a great teacher. What she wanted most of all was to offer students and practising translators general guidelines for their translational decisions. This was the rationale for most of her publications, first of all of her book on translation criticism published in 1971. The text typology she presented in this book is now an essential requisite in any theory class for trainee translators all over the world, although the translations into English (Translation Criticism - The Potentials \& Limitations) and French (La critique des traductions, ses possibilités et ses limites) were not published until 2000 and 2002, respectively. Firmly drawing on a normative concept of functional equivalence at the text level, which she never gave up, her postulate was that the method of translating is a correlate of the text type. Later, she integrated this approach as a specific theory into the framework of Hans J. Vermeer's general theory of translational action or Skopostheorie, claiming that it accounted for those special cases in which the skopos, or purpose, of the translation is to produce a textual equivalent of the source text. Of course, as an experienced translator she knew that equivalence is not always called for or even desirable. Apart from the textual categories, therefore, her model includes a functional category for those cases in which the target text is needed for another function than that of the source text. This is why she is often regarded as the founder of Skopostheorie. But for her, the source text was always the sine qua non, the necessary condition, of translation. 
On that morning in Tijuana, I told the audience, "Without Katharina Reiß I would not be here today". And those are not just words: it was Katharina Reiß who gave me the chance and even inspired me to become a translation teacher and, later, a scholar in translation studies. Her students will always remember her as a strict but fair teacher with a very subtle sense of humour. For me, she will always be the great person to whom I owe so much.

Christiane Nord

Hochschule Magdeburg-Stendal

\section{REFERENCES}

Ortega y Gasset, José (1940): Miseria y esplendor de la traducción. In: El libro de las misiones. Buenos Aires: Espasa-Calpe, 131-172.

REIss, Katharina (1971): Möglichkeiten und grenzen der übersetzungskritik [Possibilities and limitations of translation criticism]. Munich: Hueber.

Reiss, Katharina (1971/2000): Translation Criticism - The Potentials and Limitations. (Translated by Erroll F. Rhodes) New York/Manchester: American Bible Society/St. Jerome.

ReIss, Katharina (1971/2002): La critique des traductions, ses possibilités et ses limites. (Translated by Catherine BocQueT) Arras: Artois Presses Université. 